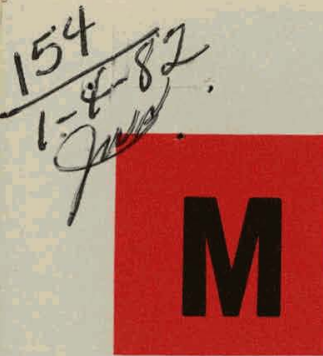

ASSACHUSETTS

DR 183

NSTITUTE OF

ECHNOLOGY

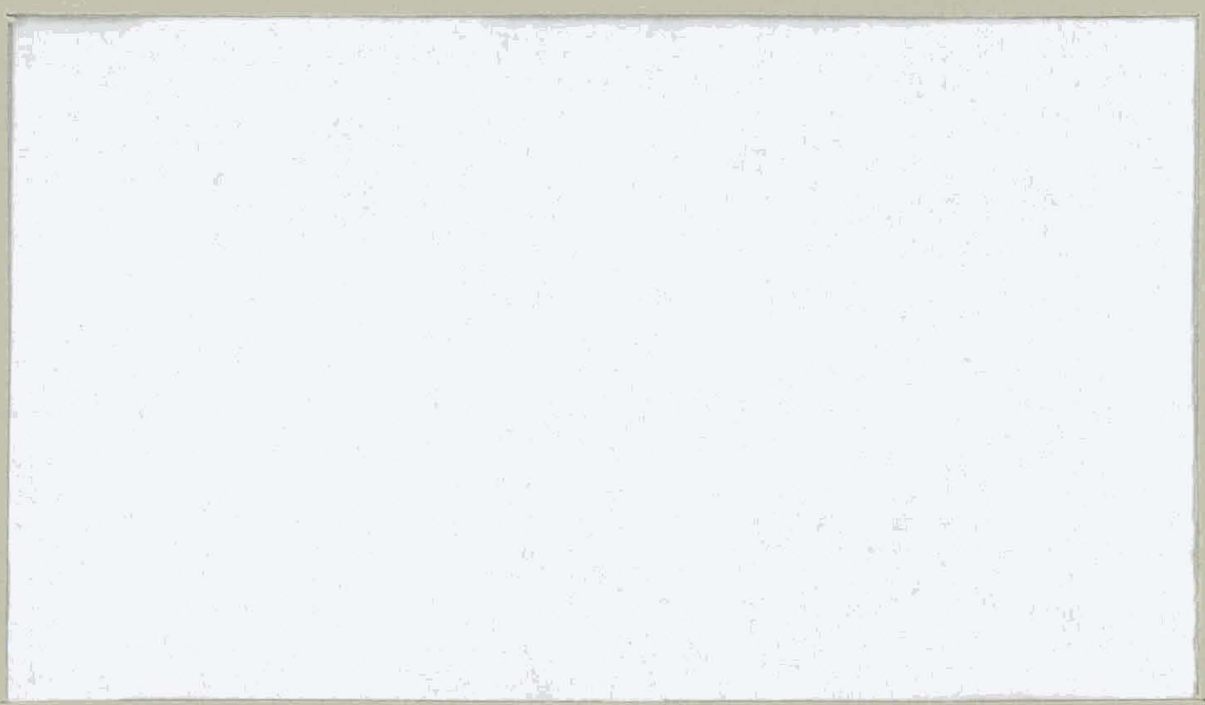

LASMA
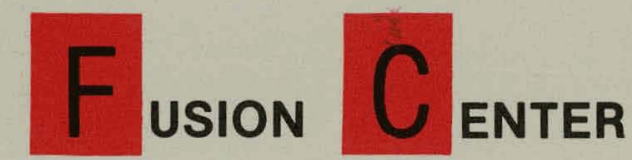

ASSOCIATED WITH

DEPARTMENT OF AERONAUTICS AND ASTRONAUTICS

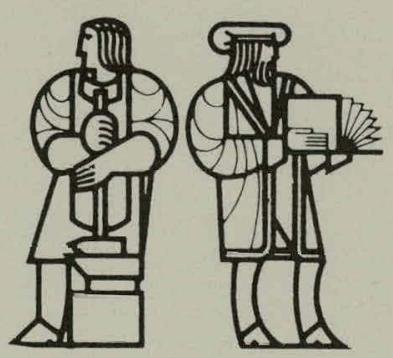

DEPARTMENT OF ELECTRICAL ENGINEERING AND COMPUTER SCIENCE

DEPARTMENT OF MATERIALS SCIENCE AND ENGINEERING

DEPARTMENT OF MECHANICAL ENGINEERING DEPARTMENT OF NUCLEAR ENGINEERING DEPARTMENT OF PHYSICS FRANCIS BITTER NATIONAL MAGNET LABORATORY RESEARCH LABORATORY OF ELECTRONICS 


\section{DISCLAIMER}

This report was prepared as an account of work sponsored by an agency of the United States Government. Neither the United States Government nor any agency Thereof, nor any of their employees, makes any warranty, express or implied, or assumes any legal liability or responsibility for the accuracy, completeness, or usefulness of any information, apparatus, product, or process disclosed, or represents that its use would not infringe privately owned rights. Reference herein to any specific commercial product, process, or service by trade name, trademark, manufacturer, or otherwise does not necessarily constitute or imply its endorsement, recommendation, or favoring by the United States Government or any agency thereof. The views and opinions of authors expressed herein do not necessarily state or reflect those of the United States Government or any agency thereof. 


\section{DISCLAIMER}

Portions of this document may be illegible in electronic image products. Images are produced from the best available original document. 


\author{
T.F. Yang \\ Plasma Fusion Center \\ Massachusetts Institute of Technology \\ Cambridge, MA 02139 \\ May, 1980
}

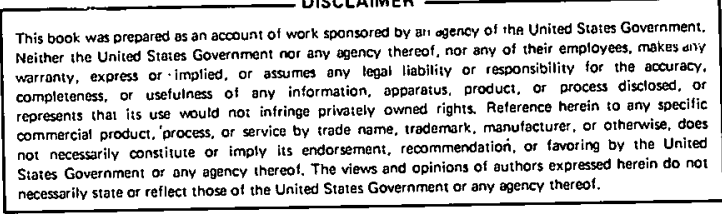




\title{
A Plan for Utilizing Alcator A \\ for Developing Actively Cooled Limiters \\ and Particle Pumping Methods
}

\author{
T. F. Yang \\ Plasma Fusion Center \\ Massachusetts Institute of Technology \\ Cambridge, Massachusetts
}

May 19,1980

\section{Purpose}

The purpose of this plan is: to develop a limiter or limiters (subjected to high heat and particle fluxes at plasma edge) for long pulse operation of tokamak fusion devices; to study the particle removal with the limiters; and to study and develop the methods for protections against disruptions and other abnormal operation, such as run-away electrons and arcing.

Alcator $A$ has a peak heat of $5 \mathrm{~kW} / \mathrm{cm}^{2}$ and high particle flux, and as such is an ideal test facility. Access is adequate for small scale tests.

\section{Limiter Types}

Active cooling methods will be developed for the conventional poloidal ring type limiter. The complete or partial toroidal rail types will be designed and studied. Innovative ideas. will be investigated.

- The conventional methods and two conceived innovative ideas are described in the following.

\section{1) Conventional ring type}

The present limiters for Alcators are poloidal rings made of molybdenum and are inertially cooled after pulses. For the purpose of comparison, a ring type, water-cooled limiter has been designed by McDonnell Douglas. The preliminary results are shown in Figure 1. The surface of the limiter is a $2 \mathrm{~mm}$ molybdenum shell bonded onto an array of copper tubes. The initial design 
study of such a limiter is underway and will be evaluated. If judged to be feasible, it will be fabricated for testing. In this conventional method, the water temperature will rise at the exit ends, and thus will reduce the heat removal efficiency. A spray cooling method: is proposed here and is illustrated by Figure 2. The surface can be coated with molybdenum or graphite or other materials. The pumping from the back side can be tested.

\section{2) Innovative concepts}

Two innovative concepts have been conceived, the spring-like coiled limiter and a series of coiled tops.. The coiled limiter is shown in Figure 3. The advantage of the coil limiter is that the plasma will reach the front as well as inner surfaces of the tubes as is illustrated by Figure $3 \mathrm{~b}$. This not only increases the surface area, but also reduces the thermal stress. It will be tested if the neutrals inside the coil can be pumped out at the ends. One can vary the pitch of the spring to determine the most effective cooling and particle removal. Because the plasma may pass through the space in between turns, two or more coil limiters may be needed. It is also possible to use a secondary cooling as is shown by Figure 3d'with counter flow coolant. It is like a heat exchanger. The primary water will be recooled at each turn so that the temperature over the entire length of the limiter will be nearly uniform and the heat removal will be more effective.

The colled top-like limiter is illustrated by Figure 4. The tops will be mounted on a duct and water lines will be connected to a manifold. The neutrals scattered into the duct can be pumped away.

The application of the coil limiters to a reactor is illustrated by Figure 5. The wlule f1rst wall can be lined with these springs. They do not have to be closely fitted together and can be easily replaced.

The purpose of the above discussion is to demonstrate that innovative methods are conceivable. Alcator-A is a valuable facility in which to carry out the testing of these methods.

\section{Testing Plan}

The testing plan is briefly outlined as follows:

- A valid concept will be designed, evaluated and tested.

- The test on the actively cooled limiters will always begin with low power. The powar will be raised gradually to highest possible level. 
- If the test is successful at normal operation, the limiters will be punished with simulated abnormal-operations such as disruption, runaway electrons, etc.

- The limiter will be subjected to many thousands of pulses to test the fatigue

- Coating of different materials with various thicknesses will be tested. Pumping techniques will be tested.

- After the successful limiters are identified, the tests will be repeated by covering the first wall area as much as possible with these limiters

\section{Participants}

The scientists who are interested in this program from other laboratories, such as Sandia and Livermore, and from industry, are invited to participate and test their own concept in coordination with M.I.T. 


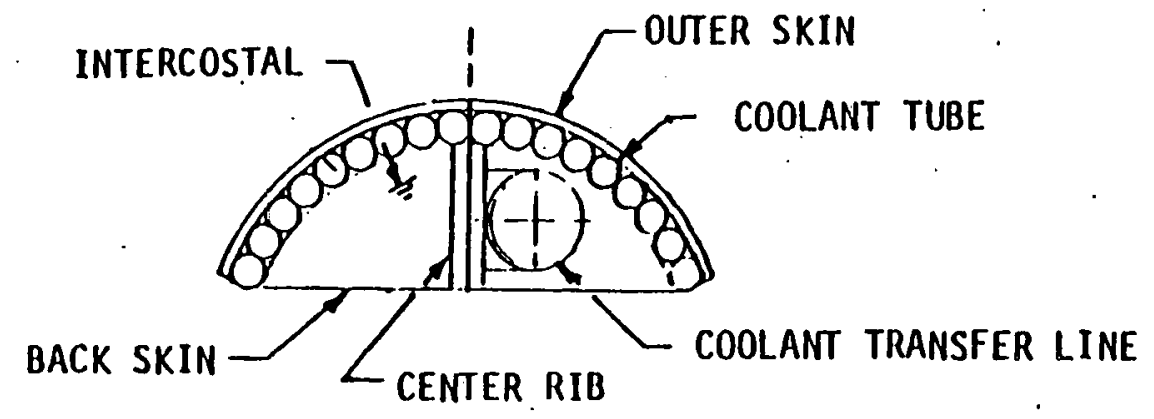

\section{MATERIALS}

$\left.\begin{array}{lcc}\text { (a) } & \frac{\text { SKIN }}{\mathrm{Cu}} & \frac{\text { TUBES }}{\mathrm{Cu}} \\ \text { (b) } & \mathrm{Ta}-10 \mathrm{~W} & \mathrm{Cu} \\ \text { (c) } & \mathrm{Mo} & \mathrm{Cu}\end{array}\right\} \begin{gathered}\text { STRUCTURE } \\ \text { Moj STL }\end{gathered}$

\section{THERMAL HYDRAULICS}

FOR $5 \mathrm{KW} / \mathrm{CM}^{2}$ PEAK HEAT FLUX:

$\begin{array}{lll}\frac{\text { CLNT }}{\mathrm{H}_{2} \mathrm{O}} & \frac{\text { SKIN MATERIAL }}{\mathrm{Cu}} & \text { SKIN TMAX } \\ \mathrm{H}_{2} \mathrm{O} & \mathrm{Ta}-10 \mathrm{~W} & 650 \\ \mathrm{H}_{2} \mathrm{O} & \mathrm{Mo} & 400 \mathrm{C} \\ & \mathrm{Co} & \mathrm{C}\end{array}$

\section{FABRICATION}

- SKIN FORMED OVER PATTERN

- TUBES, SKIN, STRUCTURE bRAZED AS UNIT

- COATING COULD BE ADDED TO SKIN 

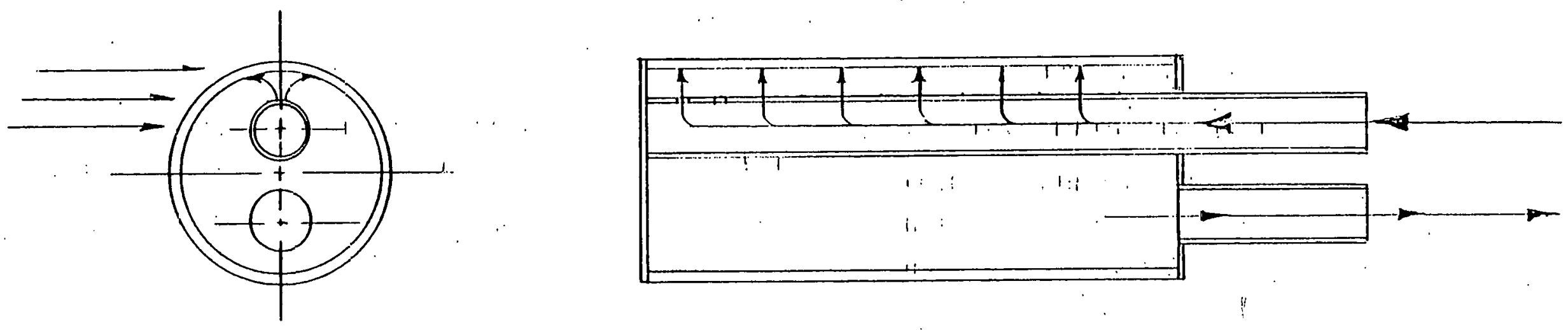

Figure 2. Sketches to Illustrate Different Cooling Methor's 


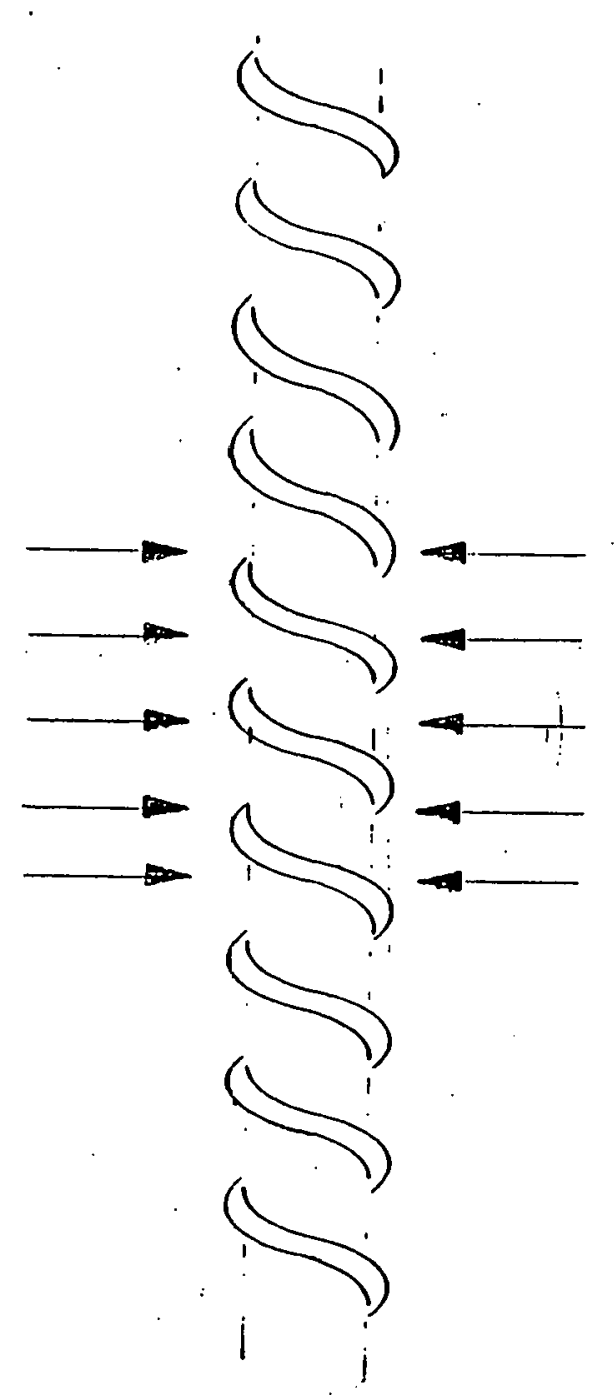

(a) coil or helical 'limiter

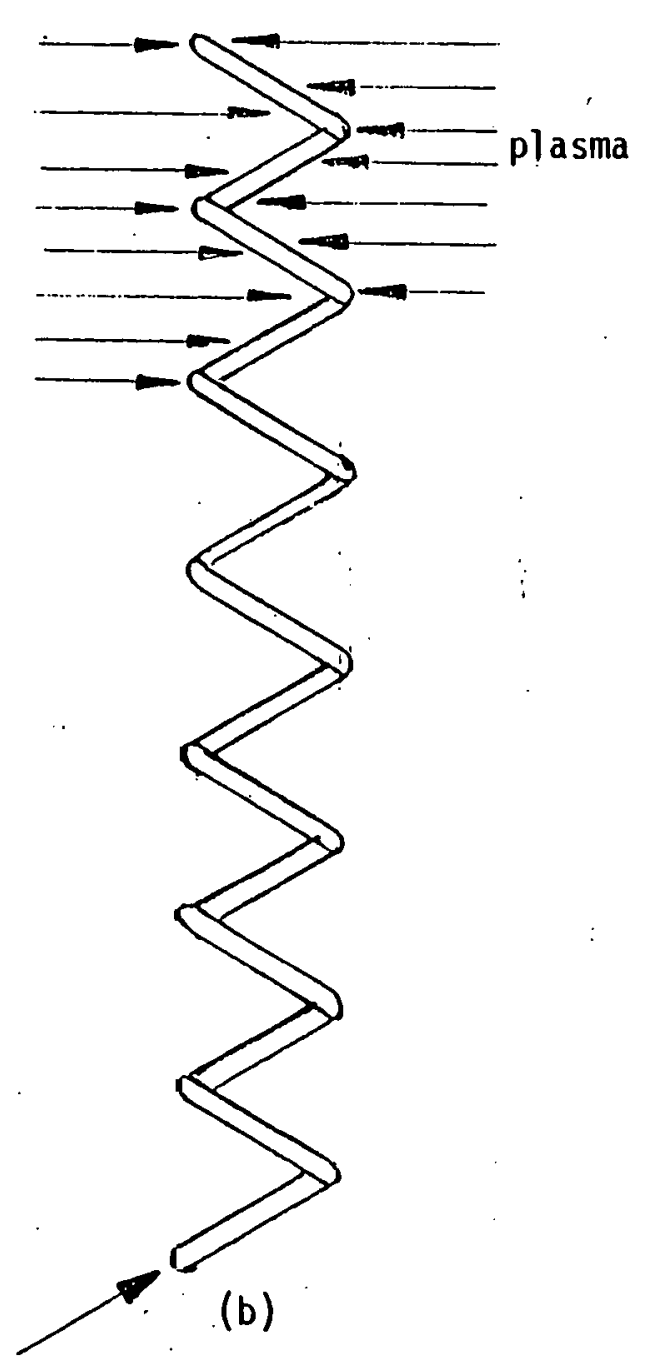

(c) concentric coil

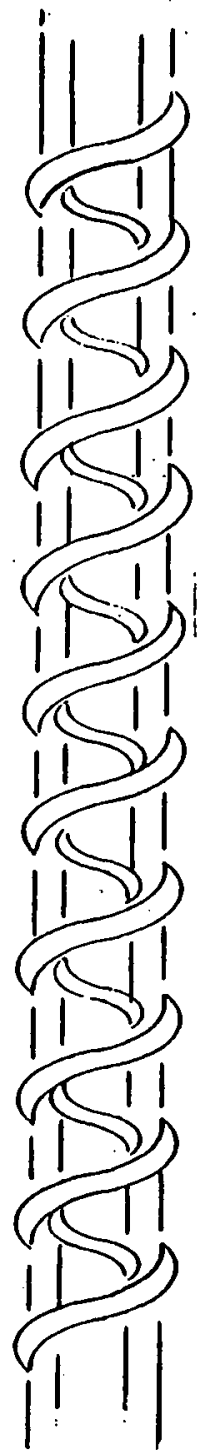

(d)

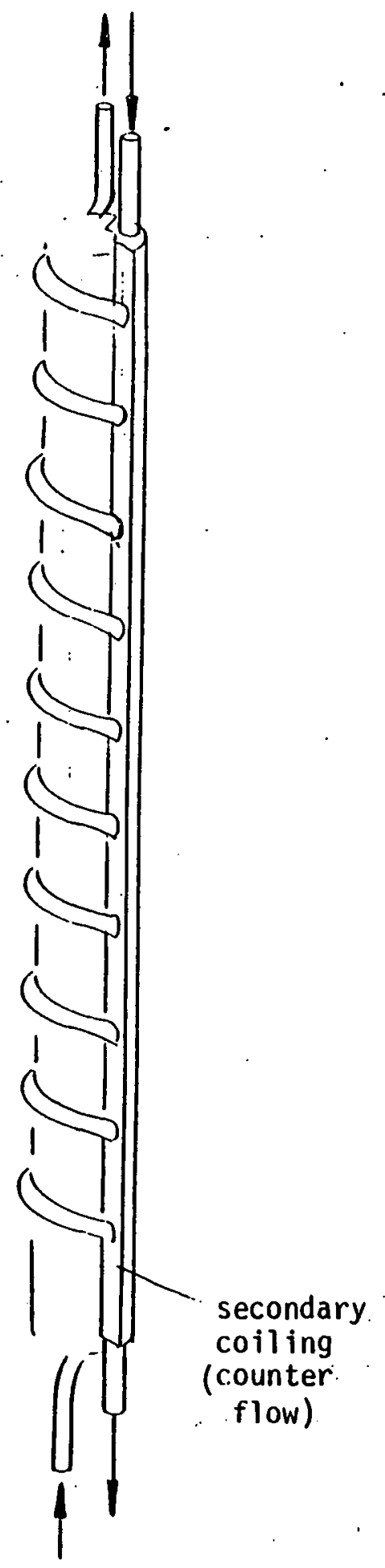

Figure. 3. Sketches to 11 lustrate helical limiters 

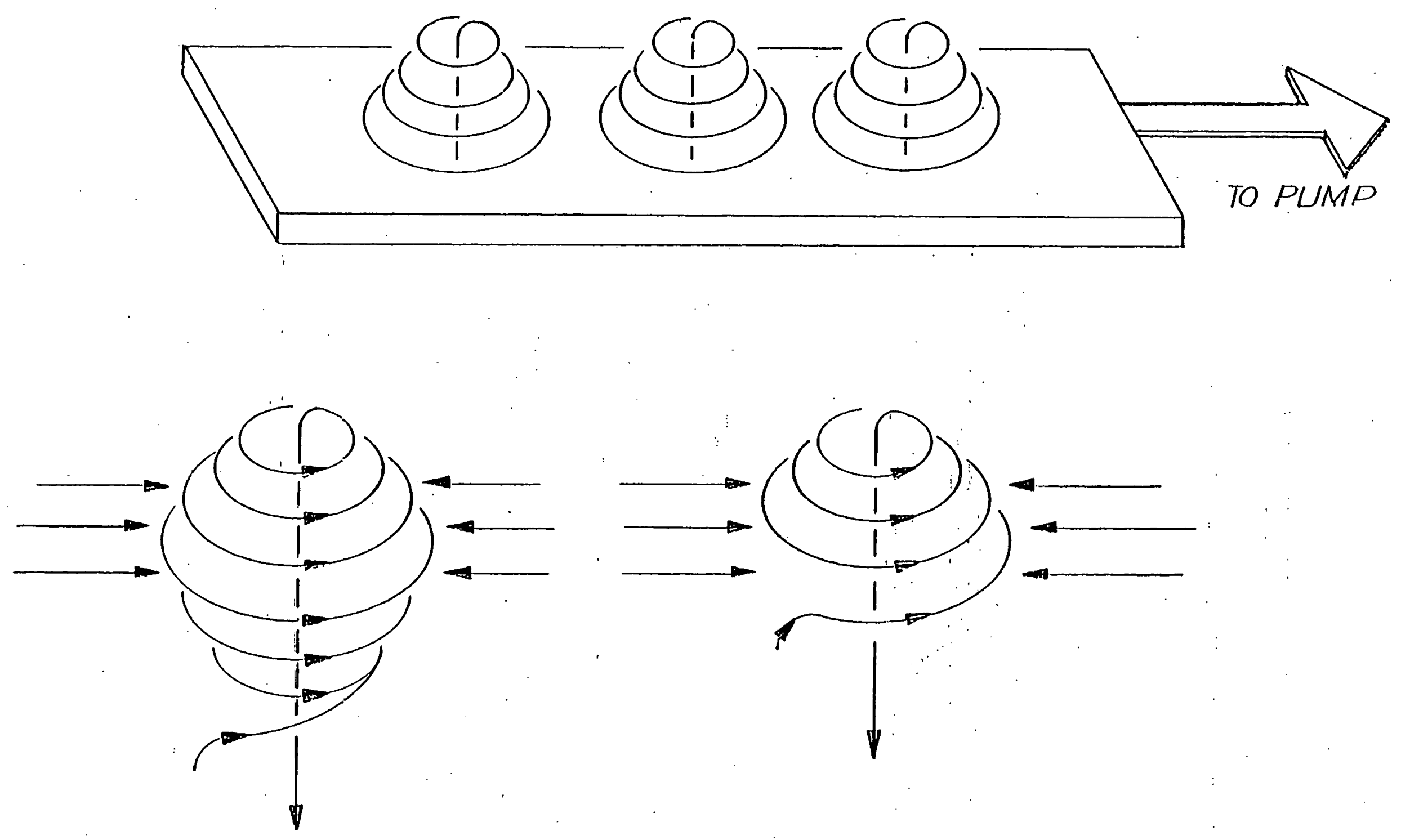

Figure 4. Sketches to illustrate coiled top limiters 
Application to Reactor
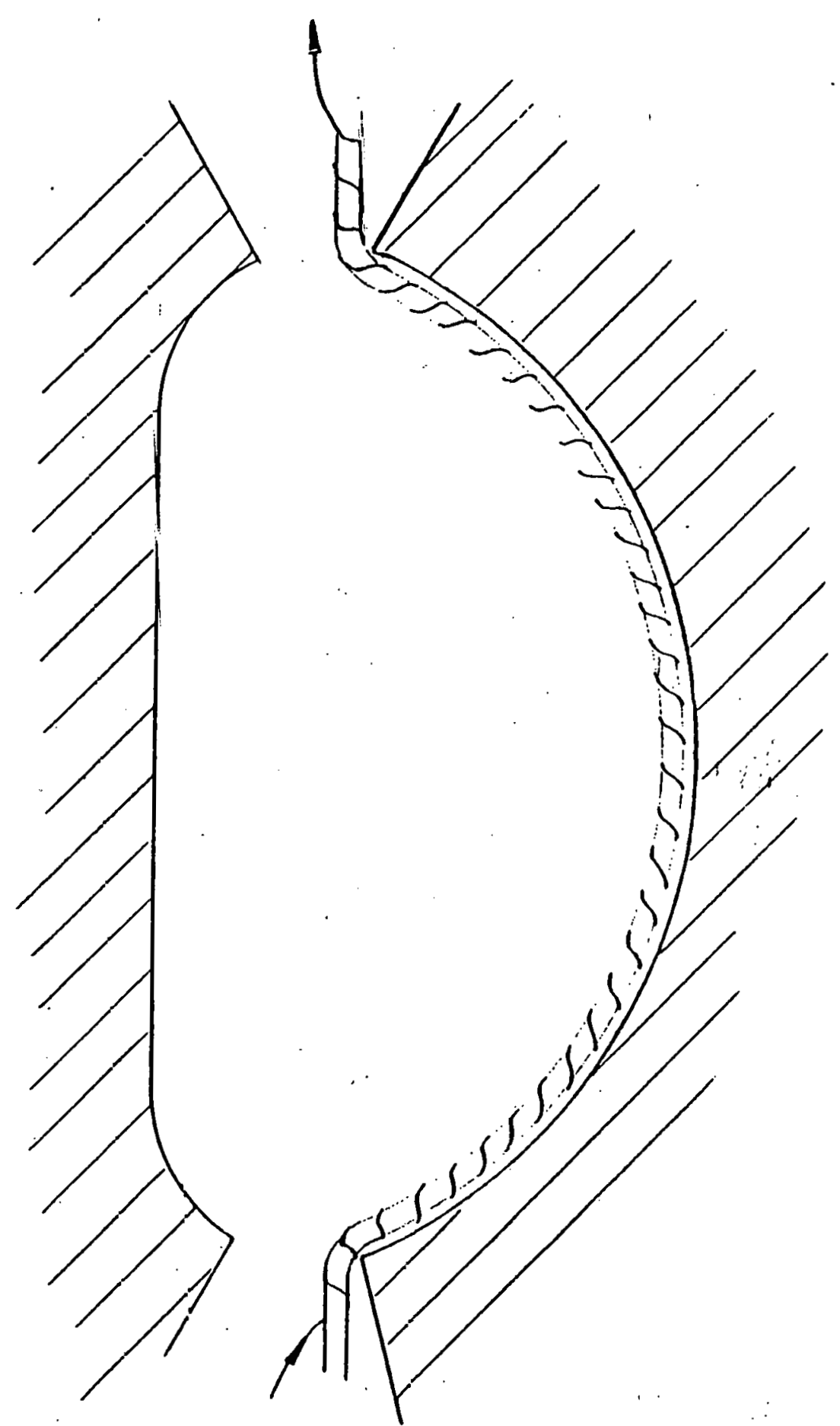

Application to Alcator

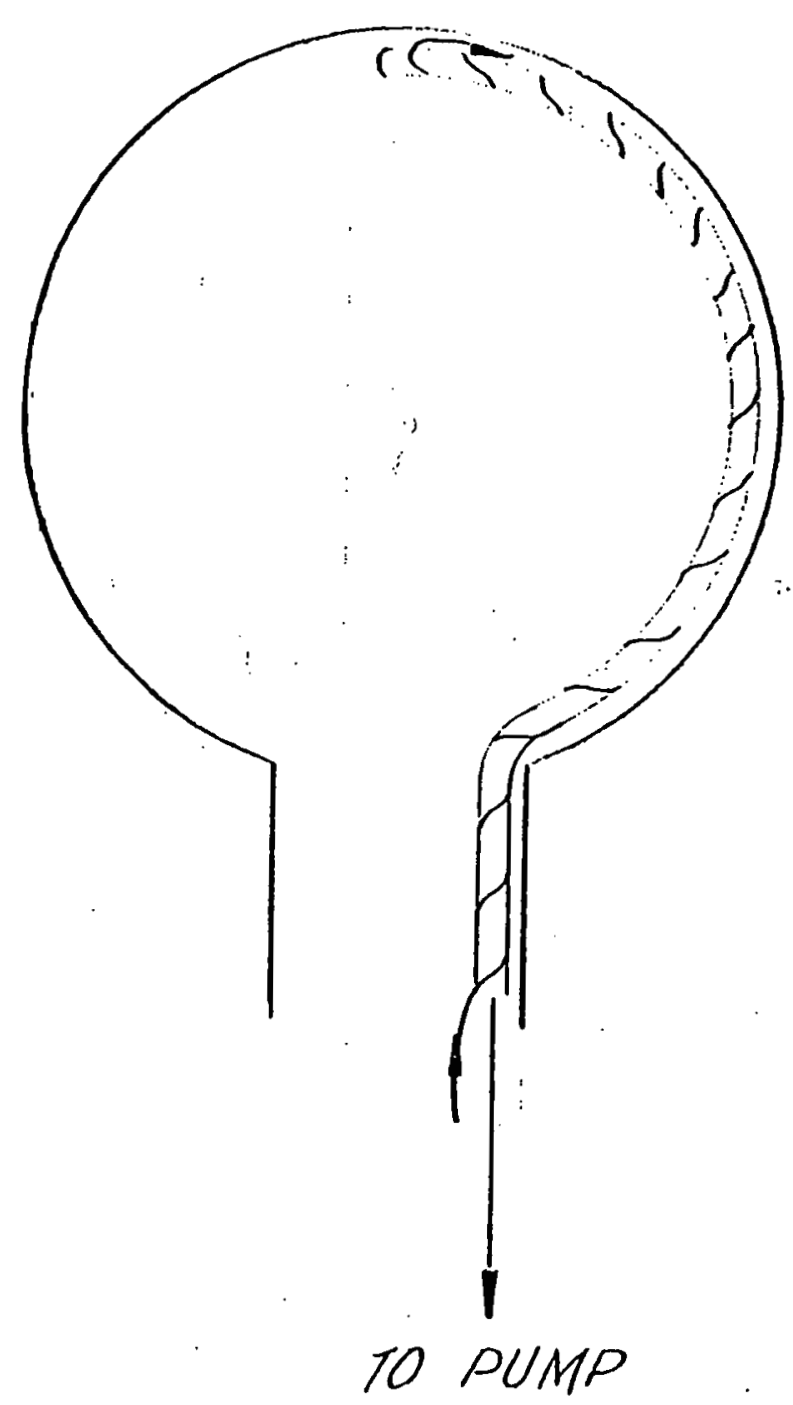

Figure 5.. Sketches to illustrate the Application to Alcator and the Reactor 

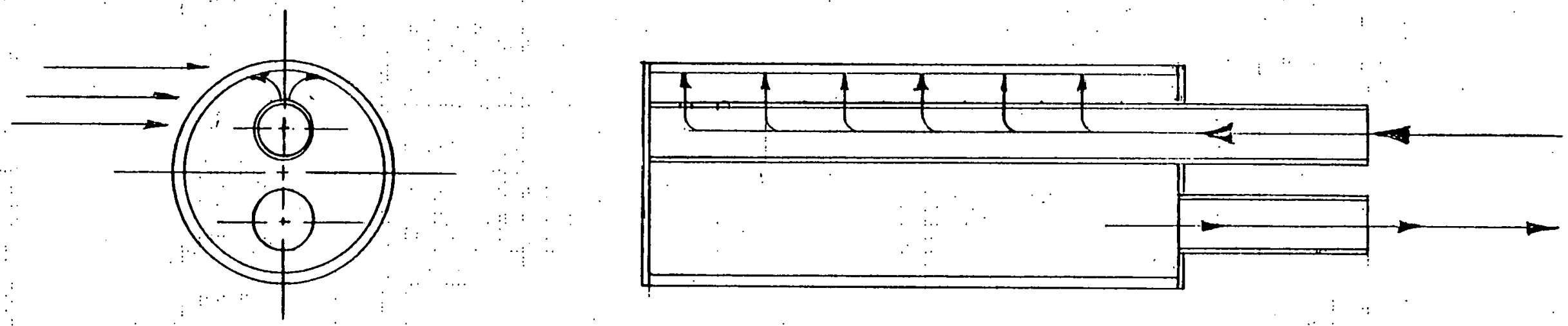

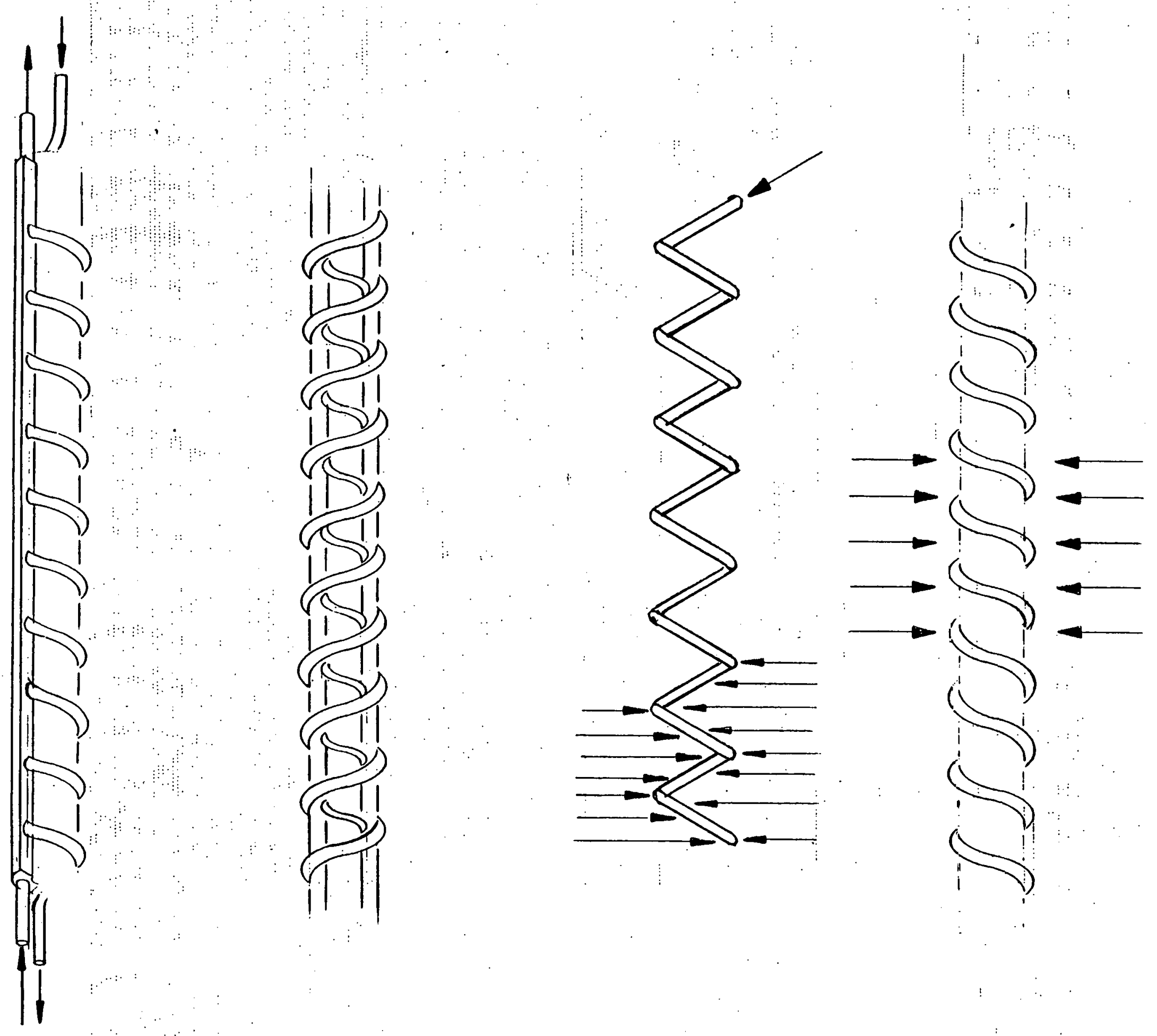


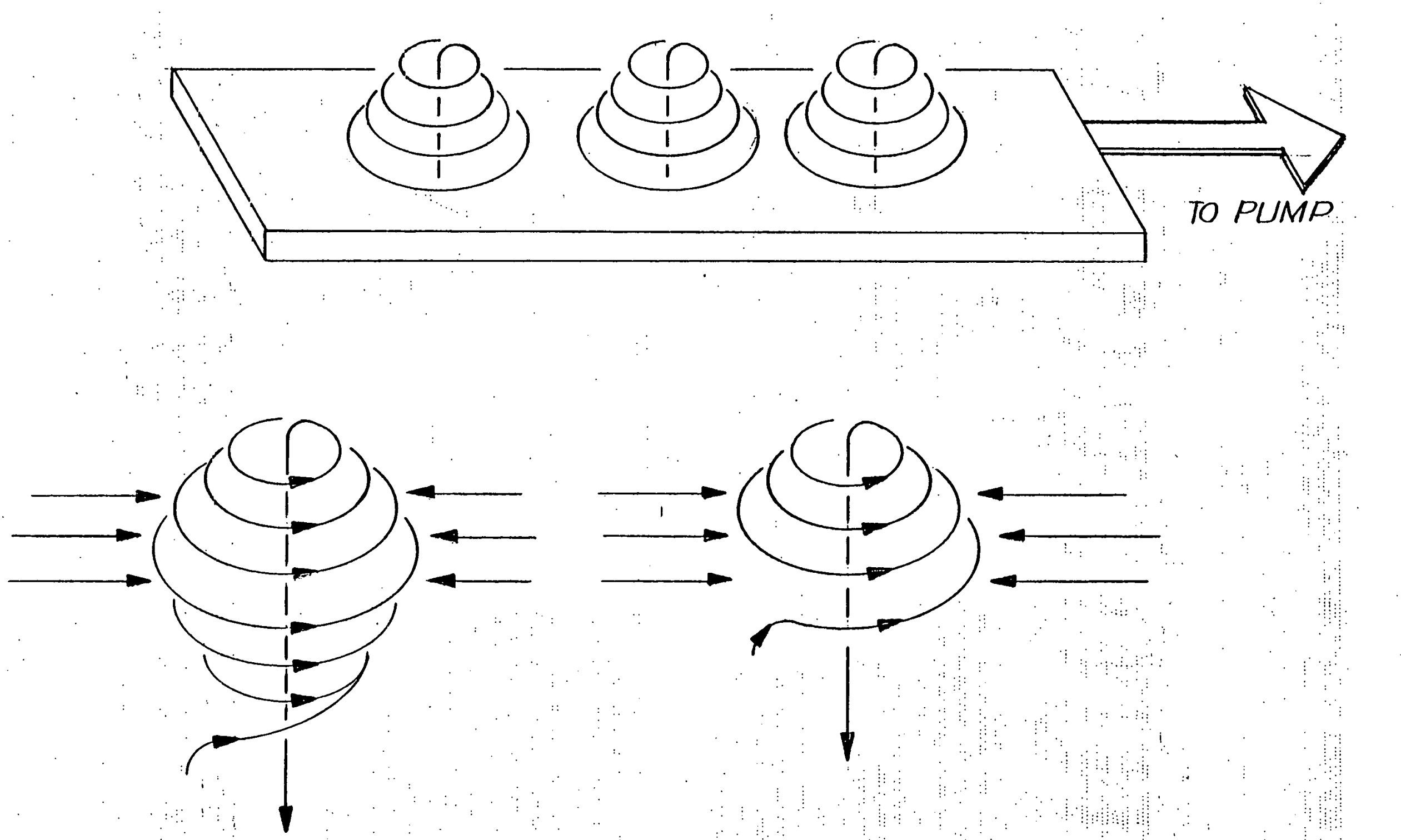




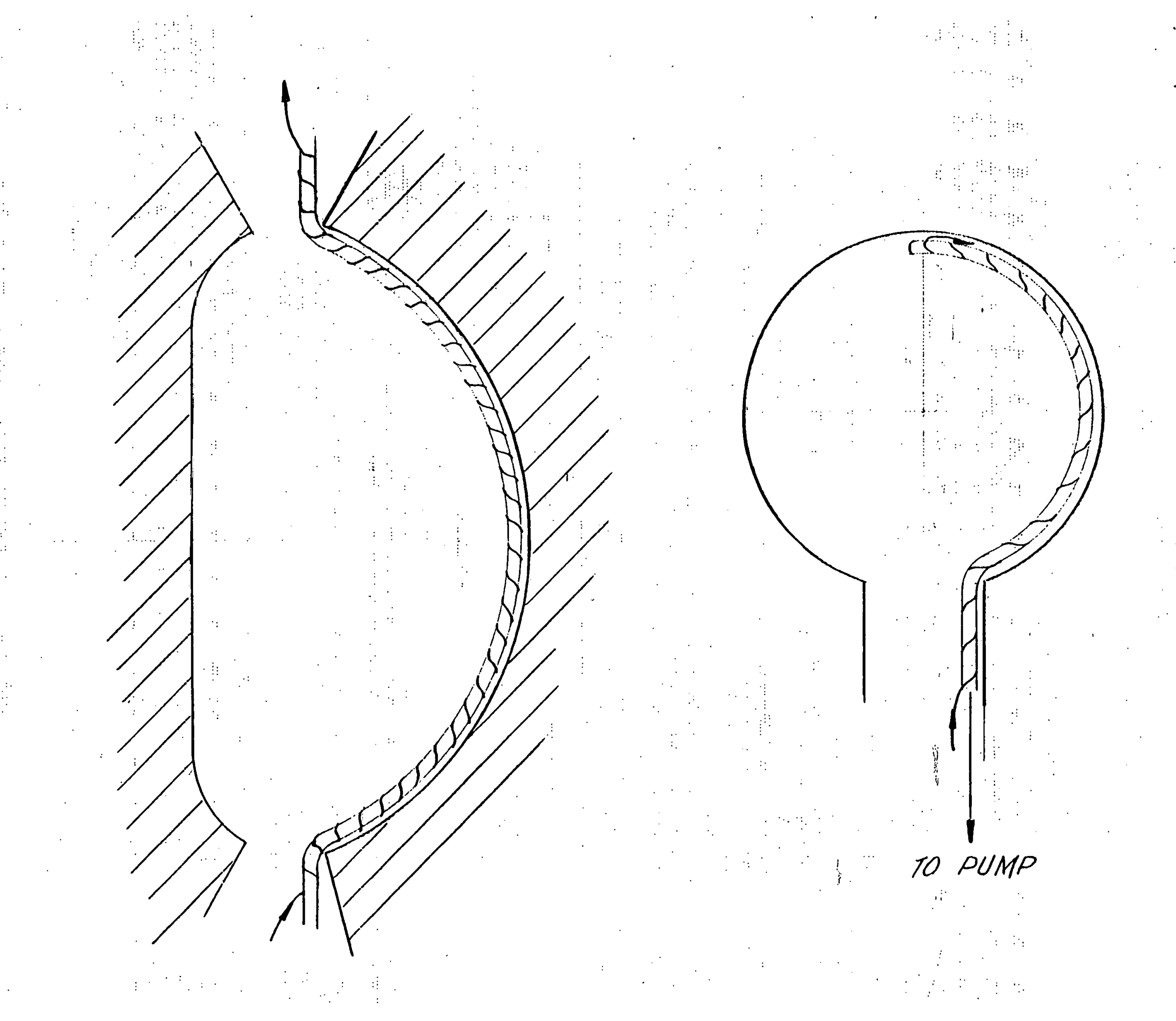




\section{LIMITER CONCEPT 1:}

\section{FORMED SKIN/COOLANT TUBES}

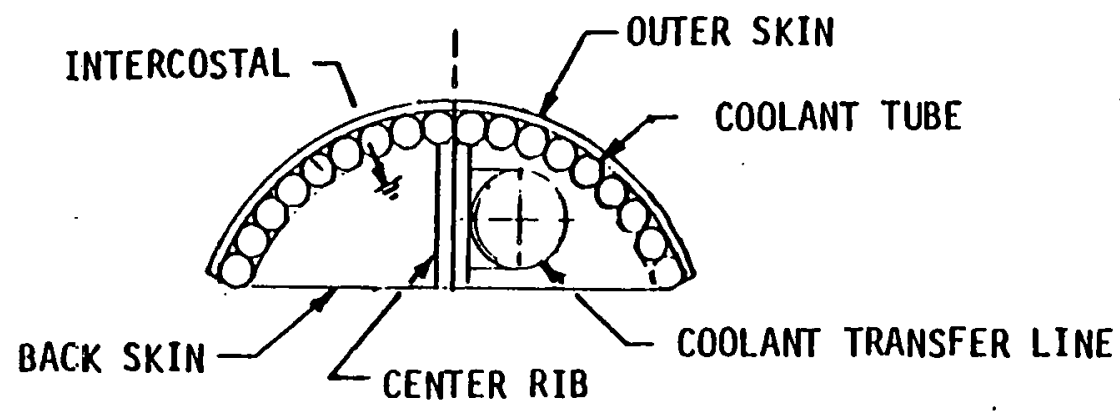

\section{MATERIALS}

$\left.\begin{array}{lcc}\text { (a) } & \frac{\text { SKIN }}{\mathrm{Cu}} & \frac{\text { TUBES }}{\mathrm{Cu}} \\ \text { (b) } & \mathrm{Ta}-1 \mathrm{lOW} & \mathrm{Cu} \\ \text { (c) } & \mathrm{Mo} & \mathrm{Cu}\end{array}\right\} \begin{gathered}\text { STRUCTURE } \\ \text { ST ST }\end{gathered}$

THERMAL HYDRAULICS

FOR $5 \mathrm{KW} / \mathrm{CM}^{2}$ PEAK HEAT FLUX:

$\begin{array}{ccc}\frac{\text { CLNT }}{\mathrm{H}_{2} \mathrm{O}} & \frac{\text { SKIN MATERIAL }}{\mathrm{Cu}} & \text { SKIN TMAX } \\ \mathrm{H}_{2} \mathrm{O} & \mathrm{Ta}-10 \mathrm{~W} & 650 \\ \mathrm{H}_{2} \mathrm{O} & \mathrm{Mo} & 400 \mathrm{C} \\ & & \end{array}$

\section{FABRICATION}

- SKIN FOPMED OVER PATTERN

- TUBES, SKIN, STRUCTURE BRAZED AS UNIT

- COATING COULD BE ADDED TO SKIN

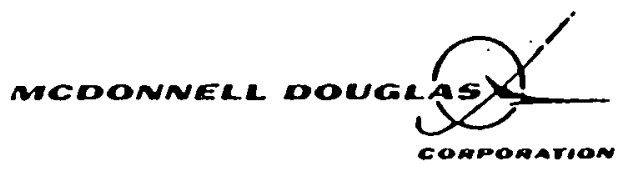


INTERNAL MAILINGS (MIT)

\section{G. Bekefi}

36-213
A. Bers
38-260
D. Cohn
NW'16-250

B. Coppi
26-201

R.C. Davidson

NW16-202

T. Dupree

38-172

S. Foner

NW14-3117

J. Freidberg

38-160

\section{A. Gondhalekar \\ NW16-278}

M.0. Hoenig

NW16-176

\section{Kazimi \\ NW12-209 \\ L. Lidsky \\ 38-174}

E. Marmar

NW16-280

J. Mccune

3 ? -265

J. Meyer

24-208

D. B. Montgomery

NW16-140

J. Moses

NE43-514

D. Pappas

N.416-272
R.R. Parker

NW16-288

N.T. Pierce

NW16-186

P. Politzer

Nil16-286

M. Porkolab

36-293

R. Post

NW21 -

H. Praddaude

NW14-3101

D. Rose

24-210

J.C. Rose

NW16-189

R.M. Rose

4-132

B.B. Schwartz

NW14-5121

R.F. Post

NW21-203.

L.O. Smul11n

38-294

R. Temkin

NW16-254

N. Todreas

NW13-202

J.E.C. Williams

NW] 4-3210

P. Wolff

36-419

$T$ : $-F$. Yang

NWT 6-164

Industrial Liaison office

ATTN: Susan Shansky

Monthly List of Publications: 39-513
MIT Libraries

Collection Development ATTN: MIT Reports

14E-210

B. Colby

PFC Library

NW16-255 
National

Argonne National Laboratory

Argonne, IL 60439

ATTN: Library Services Dept.

Battelle-Pacific Northwest Laboratory P.0. Box 99

Richland, WA 99352

ATTN: Technical Information Center

Brookhaven National Laboratory

Upton, NY 11973

ATTN: Research Library

U.S. Dept. of Energy

Washington, D.C. 20545

ATTN: D.O.E. Library

Roger Derby

Oak Ridge National Lab.

ETF Design Center

Bldg. 9204-1

Oak Ridge, TN 37830

General Atomic Co.

P.0. Box 81608

San Diego, CA 92138

ATTN: Library

Lawrence Berkeley Laboratory

1 Cyclotron Rd.

Berkeley, CA 94720

ATTN: Library

Lawrence Livermore Laboratory

UCLA

P.0. Box 808

Livermore, CA 94550

Oak Ridge National Laboratory

Fusion Energy Div. Library

Bidg. $9201-2, \mathrm{~ms} / 5$

P.0. Box "Y"

Oak Ridge, TN 37830
Dr. D. Overskei

General Atomic Co.

P.0. Box 81608

San Diego, CA 92138

Princeton Plasma Physics Laboratory

Princeton University

P.0. Box 451

Princeton, NJ 08540

ATTN: Library

Plasma Dynamics Laboratory Jonsson Engineering Center

Rensselaer Polytechnic Institute

Troy, NY 12181

ATTN: Ms. R. Reep

University of Wisconsin

Nuclear Engineering Dept.

1500 Johnson Orive

Madison, WI 53706

ATTN: UV Fusion Library 
International

Professor M.H. Brennan

Willis Plasma Physics Dept.

School of Physics

University of Sydney

N.S.W. 2006, Australia

Division of Plasma Physics

Institute of Theoretical Physics

University of Innsbruck

A-6020 Innsbruck

Austria

c/o Physics Section

International Atomic Energy Agency

Wagramerstrasse 5

P.0. Box 100

A-1400 Vienna, Austria

Laboratoire de Physique des Plasmas

c/O H.W.H. Van Andel

Dept. de Physique

Universite de Montreal

C.P. 6128

Montreal, Que H3C $3 \mathrm{J7}$

Canada

Plasma Physics Laboratory

Dept. of Physics

University of Saskatchewan

Saskatoon, Sask., Canada S7N OWO

The Library

Institute of Physics

Chinese Academy of Sciences

Beijing, China

Mrs. A. Wolff-Degives

Kernforschungsaniage Julich GmbH

Zentralbibliothek - Exchange Section

D-5170 Julich - Postfach 1913

. Federal Republic of Germany

Preprint Library

Central Research Institute for Physics

H-1525 Budapest, P.0. Box 49

Hungary

Plasma Physics Dept.

Israel Atomic Energy Commission

Soreq Nuclear Research Center

Yavne 70600

Israel
The Librarian (Miss DePa10)

Associazione EURATOM - CNEN Fusione

C.P. 65-00044 Frascati (Rome)

Italy

Librarian

Research Information Center

Institute of Plasma Physics

Nagoya University

Nagoya, 464

Japan

Dr. A.J. Hazen

South African Atomic Energy Board

Private Bag $\times 256$

Pretoria 0001

South Africa 